\title{
家畜生殖器粘液の結晶形成に関する研究
}

\section{第工報 健康乳牛の项管粘液における所見}

\author{
三 宅 勝
}

(带広畜産大学臨床繁殖学教室)

雌性動物の生殖器粘液が性周期に応じて質的にあるい は量的にいろいる変化することは古くから知られている が，逆にこれらの変化を利用して性周期の決定や妊娠診 断なぞが実施されている。然るに乳牛汇関しては僅かに 胵粘液細胞の变化飞よる性周期の判定が行われているに すぎず,これとても臨床的炕叙重要視されていない。

PAPANICOLAOU ${ }^{1)}$ は排卵時期の婦人の顽管粘液に美 しい結晶形成の拈こるのを認め, RYDBERG ${ }^{2)}$ はこれに “Fern Leaf Like Structure”と名づけた。その後 GRÜNBERGER ${ }^{3)}$, ROLAND ${ }^{4)}$, CAMPOS ${ }^{5)} ら に よ り$ 詳細 な追試が行われ，わが国に扒いても吹田6)，大谷7)，豊 島8) らを始めとして多くの研究発表があり, ·今や本現象 は婦人の有力な卵栄機能検査法の一つと認められるにい たつた。

しかるに家畜については CAMPOS $^{9}$ が少数の牛馬につ

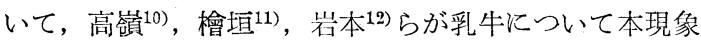
を認めているにすぎず，家畜に括ける本現象の臨床的な 意義については未知の点が多い。

私は一昨年来本現象に大変興味を覚え主として牛，馬 について研究を行いすでに一部の成績を発表しているが 本法は乳牛の発情期および授精適期の判定汇はこれ末で のいかなる粘液検査法より廷適確であり，特殊な器具も 不要でかつ操作も極めて簡単なので, 乳牛の臨床検䍒法 として十分利用しらると確信するにいたつた。

目下本結晶の本態, 乳牛以外の家畜について研究を進 めているが，ここ涀在までえられた乳牛の成績を報告 する。

\section{研究方法}

乳牛は主として本学附属第一農場汇叮い羡中の繁殖牡 牛 (2〜12 才) 便用, 頸管粘液を経日的棌取し研究 材料とした。

粘液の採取一開腟後隇菌綿花で子宮胵部定清拭，長鑷

Studies on the crystallization patterns in vaginal and cervical smears of domestic animals I. On cervical smears of dairy cows MIYAKE, M. (Obihiro Zootech. Univer., Hokkaido, ) Jap. J. Animal Reprod.1 (4).
子又は檜垣式新管粘液採取器を用いて粘液を採取し，た だちに清拭したスライドグラス上にのせて出来るだけ円 形化均等の厚さにひろげた後乾燥させた。

乾燥方法一ふつ万自然乾燥を行つているが雨天の際と か高湿度, 冬期寒冷の時期などには粘液の乾燥が捖くれ るため結晶形成が扣こりにくく判定をあやまる打それが あるためかかるさいにはアルコールランプの遠火で乾燥 させた。しかしあまり急に加熱乾燥させると結晶は変形 乙判定しにくくなるので乾燥方法には十分注意する必要 がある。

又標本鏡検のさい観察者の呼気により結晶は吸湿し消 失してしまらことがあつた。この様な際にはふたたび人 工乾燥させ鏡検に供した。これは LANDSTROM-LANG を始め多くの人が報ずる様に本結晶の主成分が $\mathrm{NaCl}$ で あるため容易飞吸湿, 潮解するためと思われる。な拝標

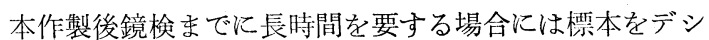
ケーター内に保存し吸湿を予防した。

鏡検はふつう 40５0 倍の低倍率で行つた。

\section{判定方法}

CAMPOS $^{5) ， G R U ̈ N B E R G E R ~}{ }^{3)}$ ，豊島8) らの分類を参考 そし，結晶の形態をつぎの様に区分して成績を判定した。

1. 結晶除性 (一) : 標本には全く結晶形成がなく糸状 粘液, 粘液小凝塊, 多くの細胞などが認められる。

2. 一部非定型結晶 $( \pm)$ : 標本のごく一部につる状, 苔状結晶が認められる。

3. 全面非定型結晶 $(+)$ : 標本の全面又は大部汇前記

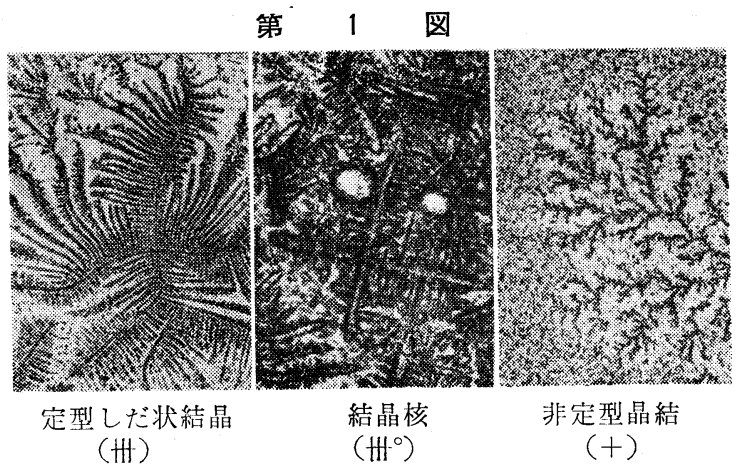


非定型結晶又は樹枝状結晶形成が認められる。

4. 一部定型結晶(サ)：一部に定型的なしだ状結晶の 出現があり他の部分には非定型結晶の出現があるかある いは全く結晶形成を認めない。

5. 全面定型結晶(卅)：全面に美しいしだ状結晶の出 現しているものである。

6. 結晶核 $\left(\mathrm{W}^{\circ}\right)$ ：全面定型結晶の出現する様な場合 しばしば標本の中央部に巨大な鋸歯状の十字針型結晶の 出現がある。GRÜNBERGER ${ }^{3)}$ はこれを結晶核と名づけ た。

以上の外, 色慾, 外陰部, 腟所見ならびに直腸検査に よる子宮，卵巣などの所見を記入し参考資料とした。

\section{研究成績および考察}

結晶形成現象と性周期との関係は第1表の様であつた。

第 1 表 乳牛の正常性周期に打忊る結晶形成

\begin{tabular}{|c|c|c|c|c|}
\hline \multirow{2}{*}{ 性周期 } & \multirow{2}{*}{ 発情よりの) 数 } & \multicolumn{3}{|c|}{ 领 管 粘 液 } \\
\hline & & 性 频 & 紹 晶 & $\begin{array}{ll}\text { 組 胞 } \\
\end{array}$ \\
\hline 登情前期 & $19 \sim 20$ & 寒天样 & --+ & + \\
\hline 燹情期 & $0 \sim 2$ & $\begin{array}{l}\text { 水美印泉 } \\
\text { 1533性 }\end{array}$ & $H \sim H^{\circ}$ & - \\
\hline 発情後期 & $3-12$ & 的白～～寒天樣 & $-\sim H$ & $t \sim \mathrm{H}$ \\
\hline 休 止 期 & $13 \sim 18$ & 寒天㴍 & - & $\mathrm{Ht}$ \\
\hline
\end{tabular}

色慾の発現していない発情前期には結晶形成は殆ど認 められないが, 色慾の出現と同時に頸管粘液は增量, 水 様, 䀠白, 汁んる性を扣び著明な結晶形成がおこる。

特に排卵の時期が接近するにつれ結晶形成は最高に達 ししばしば惯本の中央部又は濃厚とまつ部に綝晶核が出 現，排畉翌日までこの様な状態がつづいた。この様な時 期の標本では肉腿的にもあきらかに結晶の出現がわか る。豊島8)によると婦人にあつては排卵日およびその前 日，後日の 3 日閭に十字架状の結晶核が認められるとい うが，乳牛にあつてはやや一過性の様である。

この様な時期の粘液は $\mathrm{NaCl}$ の含有量が極めて高く, 高嶺3) に上ると $846 \mathrm{mg} / \mathrm{dl}$, 私 ${ }^{14)}$ も 10 例近い乳牛で平 均 $821 \mathrm{mg} / \mathrm{dl}$ という佔をえている。又石田 ${ }^{15)}$ は憱人の頸 管粘液を分析した絬果排䀧にはムチン，たん白量，遊 離糖量なよびグリコーゲンなどは著しく減量し C1 量の みが増量しているとのべている。結晶核をしさいに観察 すると中心部にはしばしば方形六面体の結晶が存在し, これらが阊状に相重りむつた像の様に思われる。私は最 近 $\mathrm{NaCl}$ ※主体としこれに卵白, 血清, 各種の糖などを 加ええ人工維晶の研究に拈いて自然の粘液絬晶と極めて
類似した結晶形成のおこるのを認め,特にある程度 $\mathrm{NaCl}$ 量を増加した場合結晶核に類似した像をえたことから結 晶形成の主体をなするのは $\mathrm{NaCl}$ と思考している。排畉 期に結晶核の出現するのは粘液中 $\mathrm{NaCl}$ の量が最高に達 するため乾燥の遅れがちな標本の中央部に $\mathrm{NaCl}$ が晶出 乙特異なる結晶像をあらわするのと思考される。

排䀠後発情徵候の消褪と共に粘液は濃稠化し結晶形成 も不明膫となりやがて長い院性期に入る。この移行の様 は個体によりいくらかの変動はあるが結晶形成現象は卵 胞の成熟するにともない顕著となり黄体形成と同時に急 激に陰性となつてゆくことから眀胞ホルモンの作用によ ることが想像され，事実これが実験的に証明されている。 従つて結晶出現の状沅が不定期になれげ体内に㧍ける畉 胞，黄体両ホルモンの不均衡が考兄られるので畉巣機能 障害の補助診断ともなり5るわけで，すでに婦人にあつ ては本法をホルモン療法などの指針としているが家畜に あつても今後この方面の研究が期待され，さらに妊娠診 断などにも利用しうるのではなからうかと考党ている。

\section{要 約}

正常性周期に扮ける乳牛の頸管粘液について結晶形成 現象を追求した結果，発情，排畉期にはしだ状結晶，結 晶核の出現を認め，非発情期にはごく一部に非定型結晶 の出現があるか又は陰性であつたことから，本法は乳牛 の授精適期の判定に利用しうるものと考えられる。

終りにのぞみ本研究は故恩们方川厚一先生, 本学上田 教授の示唆によるところが大でここに深謝する。

一部の成績は第 38 回日本獣医学会に発表した。

(1955. 11. 21受付)

\section{文献}

1) Papanicolaou, G. N. : Am. J. Obst. \& Gynec. 51, 316, 1946. 2) RYDBERG, E. : Acta Obst. Scand. 28, 172, 1948. 3) GRÜNBERGer, V. : Archiv. Gynaek. 182, 213, 1952. 4) RolAnd, M. : Am. J.Obst.\& Gynec. 63, 81, 1952. 5) CAMPOS DA PAZ, A.: Fert. \& Steril. 4, 137, 1953. 6) 吹田(清)：臨 婦产: 7, 139, 1953. 7) 大谷(羍)：産と婦. 20, 53， 1953. 8) 豊島(研)：産婦世. 6, 17, 1954. 9) CAMPOS DA PAZ, A. : 同誌 7, 15, 1955. 10) 高嶺(浩):

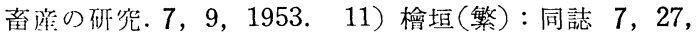
1953. 12) 岩本(研)：日息会誌. $7,466,1954.13$ ) 辟嶺 (浩)：日獣学誌. 14, 482, 1952.14 ) 三宅 (勝)：

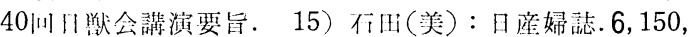
1954. 